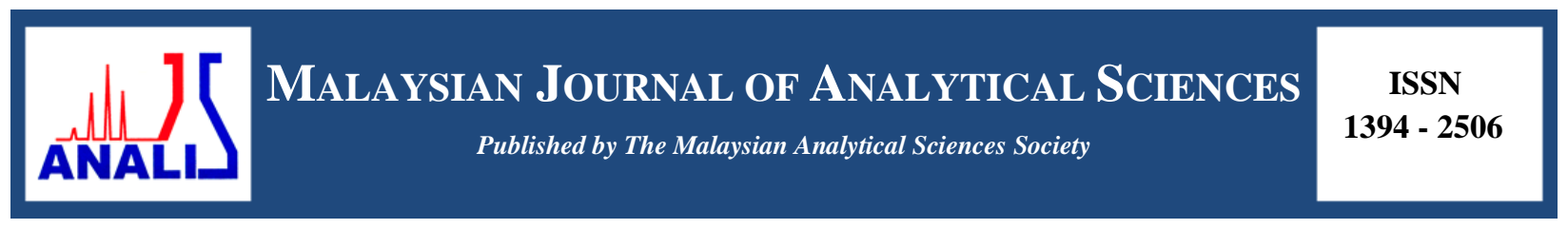

\title{
FABRICATION AND CHARACTERIZATION OF Fe-DOPED TUNGSTEN TRIOXIDE PHOTOELECTRODES IN AQUEOUS MEDIUM USING TUNGSTIC ACID AND FERROCENE AS STARTING MATERIALS
}

\author{
(Pembuatan dan Pencirian Fotoelektrod Tungsten Trioksida Terdop Fe Dalam Medium Akueus \\ Dengan Asid Tungstik dan Ferosin Sebagai Bahan Permulaan) \\ Ng Kim Hang ${ }^{1}$, Nurul Akmal Jaafar ${ }^{1}$, Lorna Jeffery Minggu ${ }^{1}{ }^{*}$, Mohammad bin Kassim ${ }^{1,2}$ \\ ${ }^{I}$ Fuel Cell Institute \\ ${ }^{2}$ School of Chemical Sciences and Food Technology, Faculty of Science and Technology \\ Universiti Kebangsaan Malaysia, 43600 UKM Bangi, Selangor, Malaysia \\ *Corresponding author: lorna_jm@ukm.edu.my
}

Received: 5 February 2016; Accepted: 22 April 2016

\begin{abstract}
Different compositions of Fe-doped tungsten trioxide thin films were synthesized on fluorine-doped tin oxide (FTO) glass substrate by sol-gel method, with ferrocene and tungstic acid as starting materials. The synthesized thin films was characterized with X-ray diffraction (XRD), scanning electron microscope (SEM), UV/Vis spectrophotometer and photoelectrochemical (PEC) analysis. The results show that the surface morphology of the thin films became rough and the grain size increased along with the concentration of $\mathrm{Fe}$. Monoclinic structure of tungsten trioxide was obtained for all doped and undoped $\mathrm{WO}_{3}$ and red-shift can be observed from UV-vis spectrum. Band gap reduced from $2.74 \mathrm{eV}$ of undoped $\mathrm{WO}_{3}$ thin films to $2.60 \mathrm{eV}$ of $20 \% \mathrm{Fe}-\mathrm{doped} \mathrm{WO}_{3}$ thin films. Photoactivities of all $\mathrm{Fe}$-doped $\mathrm{WO}_{3}$ are higher than undoped thin films. The highest photoactivities contributed by 5 $\%$ Fe-doped $\mathrm{WO}_{3}$ films with photocurrent densities measured was $0.148 \mathrm{~mA} / \mathrm{cm}^{2}$, which is 3 times higher compared to undoped $\mathrm{WO}_{3}$.
\end{abstract}

Keywords: Fe-doped $\mathrm{WO}_{3}$, direct water splitting, photoelectrochemical cell, photoanode

\section{Abstrak}

Filem nipis tungsten trioksida terdop Fe berbagai komposisi telah disediakan di atas kaca substrat FTO (fluorine-doped tin oxide) dengan kaedah sol-gel, dengan menggunakan ferosin dan asid tingstik sebagai bahan pemula. Filem nipis yang terhasil kemudiannya dicirikan dengan pembelauan sinar X (XRD), mikroskopi elektron pengimbasan (SEM), UV/Vis spektrofotometer dan analisis fotoelektrokimia. Keputusan menunjukkan bahawa morfologi permukaan filem nipis menjadi kasar dan saiz butiran bertambah dengan penambahan kepekatan Fe. Tungsten trioksida yang berstruktur monoklinik telah dihasilkan dan anjakan merah telah diperhatikan di dalam spectrum UV-vis. Jurang tenaga telah berkurang dari $2.74 \mathrm{eV}\left(\mathrm{WO}_{3}\right.$ tulen) kepada $2.60 \mathrm{eV}$ (20 $\% \mathrm{Fe}$-dop $\mathrm{WO}_{3}$ ). Fotoaktiviti $\mathrm{WO}_{3}$ terdop $\mathrm{Fe}$ adalah lebih tinggi berbanding $\mathrm{WO}_{3}$ tulen. Fotoaktiviti yang tertinggi dicatatkan oleh filem $5 \% \mathrm{WO}_{3}$ terdop Fe dengan ketumpatan fotoarus $0.148 \mathrm{~mA} / \mathrm{cm}^{2}$. Ia adalah $3 \mathrm{kali}$ ganda lebih tinggi berbanding $\mathrm{WO}_{3}$ tulen.

Kata kunci: Fe-dop $\mathrm{WO}_{3}$, pembelahan air secara langsung, sel fotoelektrokimia, fotoanod

\section{Introduction}

Hydrogen is a potential energy replacing current used of fossil fuel because it is renewable and environmentally friendly energy where the product of its consumption is only water and heat compared to fossil fuel which emit 


\section{Ng et al: FABRICATION AND CHARACTERIZATION OF Fe-DOPED TUNGSTEN TRIOXIDE PHOTOELECTRODES IN AQUEOUS MEDIUM USING TUNGSTIC ACID AND FERROCENE AS STARTING MATERIALS}

carbon based gases. Thus, hydrogen is a promising future energy [1, 2]. However, most of hydrogen production is via steam reforming which also consumes fossil fuels. In 1972, Fujishima and Honda first reported photocatalytic water splitting using semiconductor material $\mathrm{TiO}_{2}$ in 1972 [3]. Since then, photocatalytic water splitting using semiconductor catalysts received much interest from scientific community due to its potential to convert sunlight energy into chemical energy (hydrogen gas). The process of water splitting involves the excitation of electrons from the valence band during illumination. The excited electrons then moved to conduction band leaving holes in valence band. The holes on the semiconductor catalyst surface will oxidize water to produce oxygen gas and hydrogen ions while the excited electrons in conduction band moves towards the cathode to reduce the hydrogen ions into hydrogen gas [4]. The energy in excess of the band gap energy will be dissipated as heat. In practice, a semiconductor with a band gap of $1.70 \mathrm{eV}$ [5] which is greater than the energy required for water splitting reaction $(1.23 \mathrm{eV})$, can utilize maximum absorption of energy for PEC reactions [6,7]. There are several important criteria to be considered in selecting the semiconductor catalyst such as (1) favorable band edge position, (2) stability in harsh environments, (3) small band gap, and (4) photocorrosion resistance. However semiconductor catalyst that satisfy all of these criterial has yet to be found. Therefore several modifications on this photocatalyst was introduced such as fabrication of nanostructures, layered/junction, noble metal loading, and doping (anion or cation) [8-10]. In this paper, doping are our main interests because it is an alternatives approach to decrease the bandgap of semiconductor materials [11].

Tungsten trioxide $\left(\mathrm{WO}_{3}\right)$ is a good candidate in electrochromic, photochromic and sensoring applications [12 -17] and is one of the semiconductors which have the potential in water splitting when induced by sunlight. However, $\mathrm{WO}_{3}$ has a large band gap of $2.8 \mathrm{eV}$ where it can only absorb $<450 \mathrm{~nm}$ wavelength in the solar spectrum. In order to reduce the band gap, $\mathrm{WO}_{3}$ was synthesized via different methods [18-21]. The narrow band gap of $2.20-2.80 \mathrm{eV}$ helps in absorption of ultraviolet region and blue region of visible light in solar spectrum [22-25]. Furthermore, $\mathrm{WO}_{3}$ has been investigated with the aim of improving catalyst activity and stability in the irradiated aqueous environment [26-29]. Tungsten trioxide powders prepared from various $\mathrm{W}$ precursors has been studied by Bamwenda and Arakawa [30]. They found that the $\mathrm{WO}_{3}$ using tungstic acid as precursor has the lowest light absorption in long wavelength region, but it has the highest crystallinity level and photoactivity. On the other hand, iron nitrate has been used as dopant for $\mathrm{Fe}$-doped $\mathrm{TiO}_{2}$ thin film [31] and $\mathrm{Fe}$-doped $\mathrm{WO}_{3}$ powder photocatalyst [32]. Band gap of Fe-doped $\mathrm{TiO}_{2}$ reduced from $3.30 \mathrm{eV}$ to $2.89 \mathrm{eV}$ when 0.2 at. \% of $\mathrm{Fe}$ is added. Photocurrent density of 0.2 at.\% Fe-doped $\mathrm{TiO}_{2}$ is much higher than undoped $\mathrm{TiO}_{2}$. The $10 \% \mathrm{Fe}$-doped $\mathrm{WO}_{3}$ photocatalyst is able to evolve more hydrogen gas under laser illumination compared to undoped $\mathrm{WO}_{3}$. Apart from the nitrate salt, ferrocene is another Fe source that has been studied in various applications. Saremi Yarahmadi et al. [33] found that the thin films prepared using ferrocene has increased the optical absorption due to higher packing density, and improved the measured photocurrent density.

In this paper, we aim to prepare $\mathrm{Fe}$-doped $\mathrm{WO}_{3}$ photoelectrodes with ferrocene as the Fe source and tungstic acid as the $\mathrm{WO}_{3}$ precursor. Photoactivity performance of the thin film photoanode was studied as well. The film properties are discussed herein.

\section{Materials and Methods}

Fe-doped $\mathrm{WO}_{3}$ was fabricated via sol-gel method on the fluorine-doped tin oxide (FTO) glass using starting material made of Tungstic acid, $\mathrm{H}_{2} \mathrm{WO}_{4}$ (Sigma-Aldrich), ammonia aqueous (Merck, 28-30\%), ferrocene (SigmaAldrich) and PEG 300 (Merck). Other chemicals involved in this fabrication were of analytic purity grades and distilled de-ionized water. The starting material was prepared by adding the tungstic acid into aqueous ammonia which formed $0.4 \mathrm{M}$ ammonium tungstate solution. The excess ammonia from the solution was eliminated by heating. The ferrocene and PEG 300 were then added into the ammonium tungstate solution which resulted in the desired ratio of $\mathrm{W}$ to $\mathrm{Fe}(\mathrm{W}: \mathrm{Fe}=\mathrm{x}: 1-\mathrm{x}$, where $\mathrm{x}=1,0.95,0.9,0.85$ or 0.8$)$. Before the fabrication process, the FTO glass was cleaned using ultrasonic cleaner by immersing the FTO glass into three different beakers containing acetone, ethanol, and iso-propanol for 5 minutes in each beaker sequentially. The cleaned FTO glass was then coated with ferrocene-ammonium tungstate solution by doctor blading method, which formed thin films on the FTO glass. The as-deposited thin films were calcined and sintered in furnace at $500^{\circ} \mathrm{C}$ for 30 minutes with constant heating rate of $5^{\circ} \mathrm{Cs}^{-1}$. 
The calcined thin films were characterized using X-ray diffraction measurement, XRD (Bruker D8 Advance diffractometer) with $\mathrm{CuK} \alpha$ radiation, to determine the structure and crystalinity of thin films, scanning electron microscope, SEM (Zeiss AM10) to determine its morphology, grain size and thickness of the thin films, and UVVis spectrophotometer (PerkinElmer Lambda 35) to measure the absorption of the thin films. Meanwhile, the band gaps of the thin films were estimated from the UV-Vis absorption spectrum and by utilizing the Tauc formula. Photoelectrodes were prepared by attaching copper wire to the FTO glass as described by Minggu et al. [34]. The photoelectrochemical (PEC) tests of the photoelectrodes prepared was carried out in a conventional three electrodes system, which consists of working electrode (photoelectrode), counter electrode (platinum wire), and reference electrode (SCE) whereas, $0.5 \mathrm{M} \mathrm{Na}_{2} \mathrm{SO}_{4}$ was used as the electrolyte. Prior to PEC analysis, the electrolyte was purged with nitrogen gas for 30 minutes. The scan rate was set to be $0.01 \mathrm{Vs}^{-1}$. The photoelectrochemical (PEC) analyses were carried out by using Ametek Versastat 4 with 450W full arc Xenon lamp source.

\section{SEM analysis}

\section{Results and Discussion}

Figure 1 shows SEM micrographs of undoped $\mathrm{WO}_{3}$ and Fe-doped $\mathrm{WO}_{3}$ on FTO glass. The morphology of undoped $\mathrm{WO}_{3}$ is different from the $\mathrm{WO}_{3}$ thin film prepared by Yagi et al. [35] using similar method. In their study, tungstic acid was dissolved in ammonia aqueous and PEG was added but the film produced was covered with micro-scale plates. This morphological difference might be caused by the much higher molecular weight of PEG they used (PEG 20000 was used in their study). This plate-like feature can also be observed in $\mathrm{WO}_{3}$ thin film produced from tungstic hexaethoxide/PEG annealed in $300^{\circ} \mathrm{C}$ [36]. The organic residue causes the degradation in porosity and finally it forms plate. Therefore, spherical surface feature observed in this paper suggested that the organic compounds used were successfully eliminated. Morphological differences among the doped $\mathrm{WO}_{3}$ thin films can be noticed by comparing the micrographs in Figure 1.



Figure 1. SEM image of (A) undoped, (B) $10 \%$ and (C) $20 \%$ Fe-doped $\mathrm{WO}_{3}$ thin films

By comparing Fe-doped $\mathrm{WO}_{3}$ with the undoped $\mathrm{WO}_{3}$ thin films, it is noticed that surface of the Fe-doped $\mathrm{WO}_{3}$ is rough. The presence of $\mathrm{Fe}$ would lead to agglomeration of the $\mathrm{WO}_{3}$ particles. Therefore, the grain size of the Fedoped $\mathrm{WO}_{3}$ is increasing as the $\mathrm{Fe}$ content increases [37]. From cross section, the thickness of the films are approximately $1 \mu \mathrm{m}$. Taking account of the fluorine-tin oxide layer $900 \mathrm{~nm}$, the actual thickness of undoped and $\mathrm{Fe}$ doped $\mathrm{WO}_{3}$ is around $100 \mathrm{~nm}$. 


\section{Ng et al: FABRICATION AND CHARACTERIZATION OF Fe-DOPED TUNGSTEN TRIOXIDE PHOTOELECTRODES IN AQUEOUS MEDIUM USING TUNGSTIC ACID AND FERROCENE AS STARTING MATERIALS}

\section{XRD analysis}

All thin films of different Fe concentration of $\mathrm{Fe}$-doped $\mathrm{WO}_{3}$ and undoped $\mathrm{WO}_{3}$ thin films were subjected to X-ray diffraction measurement. The XRD pattern in Figure 2, which are in agreement with the Joint Committee on Powder Diffraction Standards (JCPDS) file no. 01-083-0950, displayed strongest peak at 24.4 $4^{\circ}$ which corresponding to $\left(\begin{array}{lll}2 & 0 & 0\end{array}\right)$ plane of the annealed $\mathrm{WO}_{3}$ thin films. This peak shows that the thin films were all of monoclinic, polycrystalline $\mathrm{WO}_{3}$ structure. The XRD pattern of each thin films was coincident with undoped $\mathrm{WO}_{3}$, which suggested well incorporation of $\mathrm{Fe}$ into $\mathrm{WO}_{3}$ lattice. Furthermore, additional peaks that were not detected from the patterns shown, indicates that the crystalline structure of $\mathrm{WO}_{3}$ thin films was not affected by Fe-doping with various concentration. Besides, the increment in intensity of the $\mathrm{WO}_{3}$ peaks can also be observed. This suggested that the crystallinity of $\mathrm{WO}_{3}$ is improved as the crystal defects disappear when Fe particle was added to the $\mathrm{WO}_{3}$ crystal lattice [30]. The increased in crystallinity is due to reduce nucleation centre density which favors crystal grains growth [38]. High crystalline $\mathrm{WO}_{3}$ was obtained for $20 \% \mathrm{Fe}$-doped $\mathrm{WO}_{3}$ and this effect can also be observed on Fe-doped $\mathrm{TiO}_{2}$ [31]. The main peak was shifted to lower lattice parameters due to the size of ionic radii of $\mathrm{Fe}^{2+}(0.064 \mathrm{~nm})$ [39], which was larger than $\mathrm{W}^{6+}(0.060)$ [40]. The shifted peak also suggested that $\mathrm{Fe}^{2+}$ had successfully replaced some of the $\mathrm{W}^{6+}$ in bulk $\mathrm{WO}_{3}$ lattice and thus, Fe-doped $\mathrm{WO}_{3}$ was successfully synthesized.

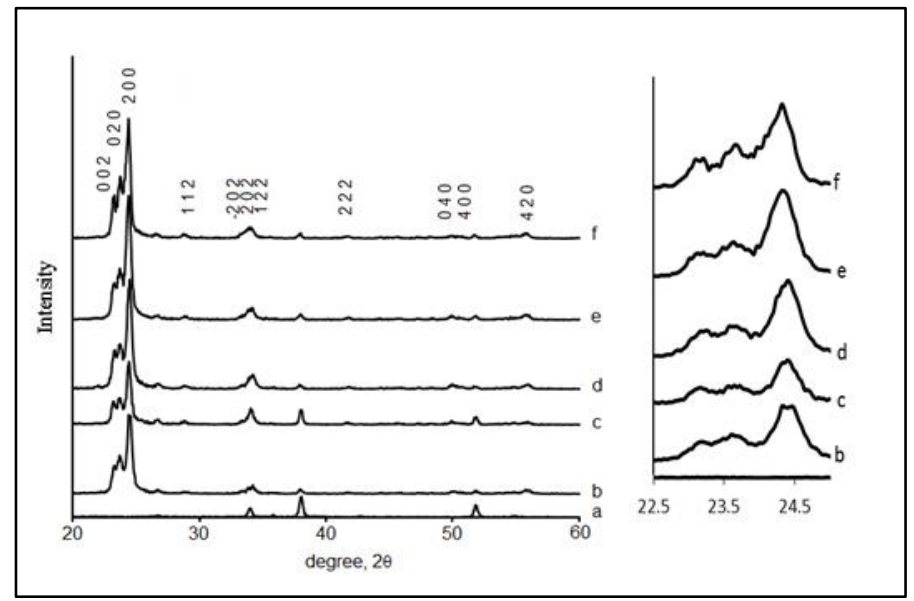

Figure 2. XRD pattern of (a) FTO, (b) undoped, (c) $5 \%$, (d) $10 \%$, (e) $15 \%$ and (f) $20 \%$ Fe-doped $\mathrm{WO}_{3}$ thin films

The average crystallite size of each thin films was estimated using the Scherrer equation by referring to the XRD pattern. The crystallite size of undoped $\mathrm{WO}_{3}$ was found to be $17 \mathrm{~nm}$, estimated based on (200) peak, which is in agreement with previous study [34]. The crystallite size remains almost the same for all the doped thin films of $5 \%$, $10 \%, 15 \%$, and $20 \%$ Fe-doped $\mathrm{WO}_{3}$. However, from the SEM measurement, the particle size is found to be larger, which is due to the agglomeration of the particle with only slight growth of crystal [41]. This indicates that the doping of $\mathrm{Fe}$ to $\mathrm{WO}_{3}$ does not alter the crystallite size.

\section{Optical charaterization}

Figure 3 shows the UV-vis absorption spectra of the undoped and Fe-doped $\mathrm{WO}_{3}$ thin films. From the Figure, it is observed that the spectrums are shifted to higher wavelength, which is also known as the red-shift in light absorption. The red shift shows that the band gap of Fe-doped $\mathrm{WO}_{3}$ thin films was reduced compared to the undoped sample. To estimate the optical band gap, $\mathrm{E}_{\mathrm{g}}$ of the thin films, equation (1) and (2) below were used [42]

$$
\begin{aligned}
& \mathrm{T}=\mathrm{e}^{-\alpha \mathrm{d}} \\
& \alpha h \nu=B\left(h v-E_{g}\right)^{\mathrm{n}}
\end{aligned}
$$


From equation (1), $\alpha$ is the optical absorption coefficient, $\mathrm{T}$ is measured spectral transmittance, and $\mathrm{d}$ is thickness of the film (cm). Meanwhile from equation (2), B is a constant, $n$ is the exponent where, $n=1 / 2,3 / 2,2$, and 3 when the transition is direct allowed, direct forbidden, indirect allowed and indirect forbidden, respectively for crystalline semiconductors. The band gap of the thin films was estimated by plotting $(-\operatorname{InT})^{1 / 2}$ against energy $(\mathrm{h} v)$ for undoped and Fe-doped $\mathrm{WO}_{3}$ thin films, assuming the materials are indirect semiconductors. The band gap of the undoped $\mathrm{WO}_{3}$ is $2.74 \mathrm{eV}$ and it is in agreement with previous studies [22-26]. Meanwhile, the band gap of the doped thin films was decreased to $2.60 \mathrm{eV}$ as the concentration of Fe increased up to $20 \%$. This band gap reduction was attributed to the doping of $\mathrm{Fe}$ into the $\mathrm{WO}_{3}$ lattice, as shown in XRD pattern.

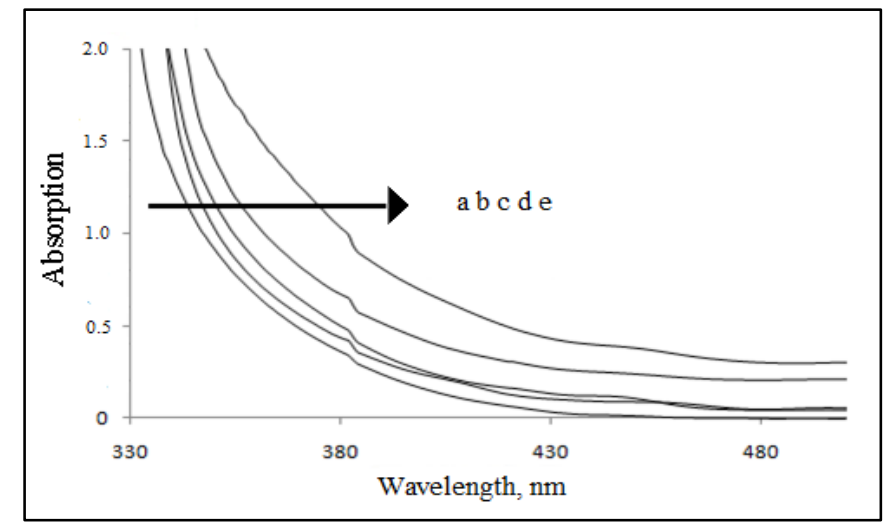

Figure 3. UV-Vis spectrum of (a) undoped, (b) $5 \%$, (c) $10 \%$, (d) $15 \%$ and (e) $20 \%$ Fe-doped $\mathrm{WO}_{3}$ thin films

\section{PEC analysis}

The photocatalyst of undoped and $\mathrm{Fe}$-doped $\mathrm{WO}_{3}$ thin film performance was studied by measuring the photocurrent densities by applying potential $(0 \mathrm{~V}$ to $1.5 \mathrm{~V})$ in $0.5 \mathrm{M} \mathrm{Na}_{2} \mathrm{SO}_{4}$ as electrolyte, under full arc xenon lamp irradiation $\left(100 \mathrm{mWcm}^{-2}\right)$. The photocurrents are calculated by subtracting the measured currents under light irradiation with the respective dark currents. Figure 4 shows the photocurrent density of undoped and $\mathrm{Fe}$-doped $\mathrm{WO}_{3}$ thin films.

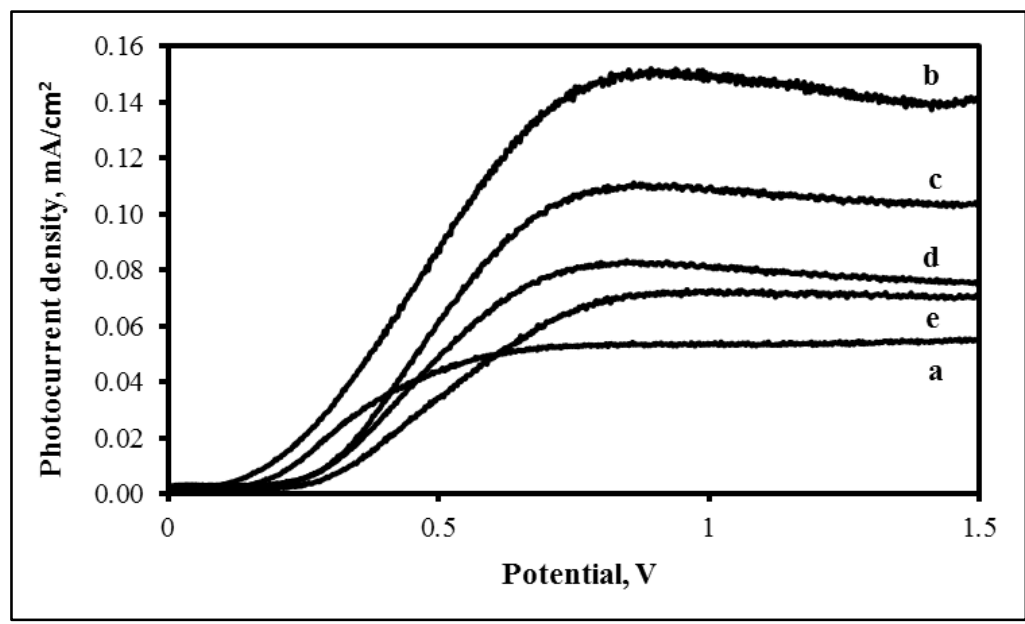

Figure 4. PEC analysis of (a) undoped, (b) $5 \%$, (c) $10 \%$, (d) $15 \%$ and (e) $20 \% \mathrm{Fe}$-doped $\mathrm{WO}_{3}$ thin films 


\section{Ng et al: FABRICATION AND CHARACTERIZATION OF Fe-DOPED TUNGSTEN TRIOXIDE PHOTOELECTRODES IN AQUEOUS MEDIUM USING TUNGSTIC ACID AND FERROCENE AS STARTING MATERIALS}

Figure 4 shows that the photocurrents produced by $\mathrm{Fe}$-doped $\mathrm{WO}_{3}$ photoelectrodes are higher compared to the undoped $\mathrm{WO}_{3}$ under the same bias potential of $0.8 \mathrm{~V}$. This indicates that under the same irradiation of $100 \mathrm{mWcm}^{-2}$ with the same bias potential of $0.8 \mathrm{~V}$, the flow of photoexcited electrons of $\mathrm{Fe}$-doped $\mathrm{WO}_{3}$ electrode are more than the electron flow of the undoped $\mathrm{WO}_{3}$ electrode via external circuit towards the cathode. As the electron leaving, the photoexcited holes remains at the surface of the photoelectrodes, which eventually drives the oxidation reaction. The high photoactivity with $\mathrm{Fe}$-doped electrode was due to the $\mathrm{Fe}$ particles in $\mathrm{WO}_{3}$ lattice act as electron acceptors, which helps in charge separation and thus, contributes to the improvement of photocurrent in $\mathrm{Fe}$-doped $\mathrm{WO}_{3}$. However, we observed that the photocurrent saturation potential of $\mathrm{Fe}$-doped $\mathrm{WO}_{3}$ were higher than the undoped $\mathrm{WO}_{3}$. A high potential was needed to achieve the highest photocurrent production. This might be due to the rapid recombination rate in iron oxide as it has short carrier diffusion length of 2-4 $\mathrm{nm}$ [21].

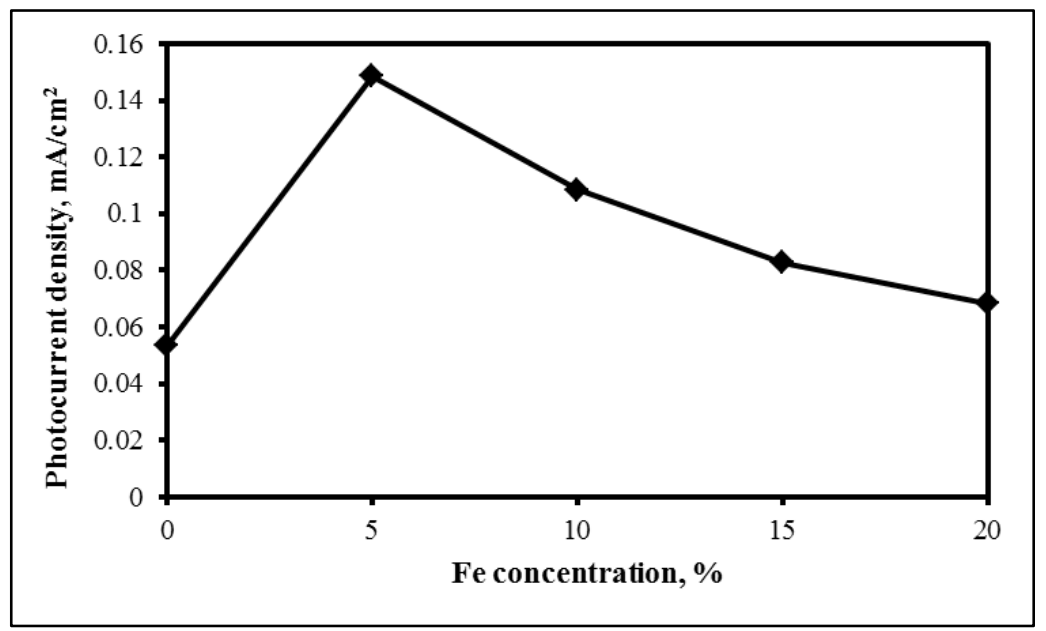

Figure 5. Photocurrent density versus Fe concentration of $0 \%, 5 \%, 10 \%, 15 \%$ and $20 \%$ at $0.8 \mathrm{~V}$ vs SCE

The photogenerated charges (electron-holes) are easily separated by supplying bias to the PEC system and the reduction and oxidation reaction (process of splitting of water and generation of hydrogen) occurs at physically different electrode. Hence, surface recombination is not the main contribution of photogenerated charges recombination. However, the main contribution is from the recombination that occurs during the electron flows through photocatalyst films and the movement of holes towards the electrode-water interface which is known as volume recombination [43]. Comparing among the Fe-doped $\mathrm{WO}_{3}$ thin films, the photocurrent density of the sample with $5 \%$ of $\mathrm{Fe}$ is the highest and it is decreasing with the increase in concentration of $\mathrm{Fe}$ in the thin films (Figure 5). This is because of the grain size of the sample increases as the concentration of Fe increases, causing the volume recombination of electron-hole pair increases. Therefore, in this study, $5 \%$ fe-doped $\mathrm{WO}_{3}$ electrode exhibits the best water splitting capability than the others under xenon light irradiation.

\section{Conclusion}

In this paper, we have described the fabrication of $\mathrm{WO}_{3}$ doped with different concentration of $\mathrm{Fe}$ and undoped $\mathrm{WO}_{3}$ thin films via sol-gel method, using ferrocene and tungstic acid as starting materials. The XRD result of thin films with different $\mathrm{Fe}$ concentration has shown that all $\mathrm{WO}_{3}$ thin films are in monoclinic form and also shows the $\mathrm{Fe}$ particles are successfully incorporated into $\mathrm{WO}_{3}$ lattice. The Fe-doped $\mathrm{WO}_{3}$ thin films show red-shift in UV-vis absorption spectra which corresponding to band gap reduction. Also, photoelectrohemical analysis shows that thin films of $5 \% \mathrm{Fe}$-doped $\mathrm{WO}_{3}$ produce the highest photocurrent under the full arc xenon lamp irradiation. The photocurrent of $5 \% \mathrm{Fe}$-doped $\mathrm{WO}_{3}$ is 3 times higher compared to undoped $\mathrm{WO}_{3}$. 


\section{Acknowledgement}

The authors would like to acknowledge Universiti Kebangsaan Malaysia for sponsoring this project under UKMGUP-BTT-07-30-189.

\section{References}

1. Ab Hamid, N. Z., Md Jahim, J., Anuar, N. and Khalid, S. (2012). Hydrogen production via rhodobacter sphaeroides NCIMB 8253. Sains Malaysiana, 41(12): 1587 - 1593.

2. Wun Fui, M. L., Minggu, L. J. and Kassim, M. B. (2012). Photo-chemical properties of molybdenum dithiolene. Sains Malaysiana, 41:597 - 601.

3. Fujishima, A. and Honda, K. (1972). Electrochemical photolysis of water at a semiconductor. Electrode Nature 238: $37-38$.

4. Ni, M., Leung, M. K. H., Leung, D. Y. C. and Sumathy, K. (2008). A review and recent developments in photocatalytic water-splitting using $\mathrm{TiO}_{2}$ for hydrogen production. Renewable and Sustainable Energy Reviews, 11: $401-425$.

5. Weber, M. F. and Dignam, M. J. (1986). Splitting water with semiconducting photoelectrodes-efficiency considerations. International Journal of Hydrogen Energy, 11: 225 - 232.

6. Bolton, J. R, Strickler, S. J. and Connolly, J. S. (1985). Limiting and realizable efficiencies of solar photolysis of water. Nature, 316: $495-500$.

7. Murphy, A. B., Barnes, P. R. F., Randeniya, L. K., Plumb, I. C., Grey, I. E., Horne, M. D. and Glasscock, J. A. (2006). Efficiency of solar water splitting using semiconductor electrodes. International Journal of Hydrogen Energy, 31:1999- 2017.

8. Li, Y., Yu, H., Zhang, C., Fu, L., Li, G., Shao, Z. and Yi, B. (2013). Enhancement of photoelectrochemical response by au modified in $\mathrm{TiO}_{2}$ nanorods. International Journal of Hydrogen Energy 36: $14374-14380$.

9. Minggu, L. J., Ng, K. H., Kadir, H. A. and Kassim, M. B. (2014). Bilayer n- $\mathrm{WO}_{3} / \mathrm{p}-\mathrm{Cu}_{2} \mathrm{O}$ photoelectrode with photocurrent enhancement in aqueous electrolyte photoelectrochemical reaction. Ceramics International, 40: $16015-16021$.

10. Rahman, G. and Joo, O. S. (2012). Photoelectrochemical Water Splitting at Nanostructured $\alpha-\mathrm{Fe}_{2} \mathrm{O}_{3}$ Elecrodes. International Journal of Hydrogen Energy 37: 13989-13997.

11. Pung, S. Y., Ong, C. S., Mohd Isha, K. and Othman, M. H. (2014). Synthesis and characterization of Cu-doped ZnO nanorods. Sains Malaysiana, 43(2): 273 - 281.

12. Gavrilyuk, A. I. (1999). Photochromism in $\mathrm{WO}_{3}$ thin films. Electrochimica Acta 44: 3027 - 3037.

13. He, T. and Yao, J. N. (2006). Photochromism in composite and hybrid materials based on transition-metal oxides and polyoxometalates. Progress in Materials Science, 51: 810 - 879.

14. Kawasaki, H., Ueda, T., Suda, Y. and Ohshima, T. (2004). Properties of metal doped tungsten oxide thin films for $\mathrm{NO}_{\mathrm{x}}$ gas sensors grown by PLD method combined with sputtering process. Sensors and Actuators B, 100: $266-269$.

15. Monk, P. M. S., Akhtar, S. P., Boutevin, J. and Duffield, J. R. (2001). Toward the tailoring of electrochromic bands of metal-oxide mixtures. Electrochimica Acta 46: 2091 - 2096.

16. Svensson, J. S. E. M. and Granqvist, C. G. (1985). Electrochromic coatings for smart windows. Solar Energy Materials, 12: $391-402$.

17. Teowee, G., Gudgel, T., McCarthy, K., Agrawal, A., Allemand, P. and Cronin, J. (1999). User Controllable Photochromic (UCPC) Devices. Electrochimica Acta, 44: 3017 - 3026.

18. Avellaneda, C. O. and Bulhões, L. O. S. (2003). Photochromic properties of $\mathrm{WO}_{3}$ and $\mathrm{WO}_{3}: \mathrm{X}(\mathrm{X}=\mathrm{Ti}, \mathrm{Nb}, \mathrm{Ta}$ and $\mathrm{Zr}$ ) thin films. Solid State Ionics, 165: 117 - 121.

19. Finlason, A. P., Ward, E., Tsaneva, V. N. and Glowacki, B. A. (2005). $\mathrm{Bi}_{2} \mathrm{O}_{3}-\mathrm{WO}_{3}$ compounds for photocatalytic applications by solid state and viscous processing. Journal of Power Sources 145: $667-674$.

20. Karuppasamy, K. M. and Subrahmanyam, A. (2008). The electrochromic and photocatalytic properties of electron beam evaporated vanadium-doped tungsten oxide thin films. Solar Energy Materials and Solar Cells, 92: $1322-1326$.

21. Memar, A., Phan, C. M. and Tade, M. O. (2012). Influence of surfactants on $\mathrm{Fe}_{2} \mathrm{O}_{3}$ nanostructure photoanode. International Journal of Hydrogen Energy, 37: 16835 - 16843

22. Scarminio, J., Urbano, A. and Gardes, B. (1999). The Beer-Lambert Law for electrochromic tungsten oxide thin films. Materials Chemistry and Physics, 61: 143 - 146. 
$\mathrm{Ng}$ et al: FABRICATION AND CHARACTERIZATION OF Fe-DOPED TUNGSTEN TRIOXIDE PHOTOELECTRODES IN AQUEOUS MEDIUM USING TUNGSTIC ACID AND FERROCENE AS STARTING MATERIALS

23. Sivakumar, R., Jayachandran, M. and Sanjeeviraja, C. (2004). Studies on the effect of substrate temperature on (VI-VI) textured tungsten oxide $\left(\mathrm{WO}_{3}\right)$ thin films on glass, $\mathrm{SnO}_{2}: \mathrm{F}$ substrates by PVD:EBE technique for electrochromic devices. Materials Chemistry and Physics, 87: 439 - 445.

24. Su, L., Wang, H. and $\mathrm{Lu}, \mathrm{Z}$. (1998). All-solid-state electrochromic window of prussian blue and electrodeposited $\mathrm{WO}_{3}$ film with poly(ethylene oxide) gel electrolyte. Materials Chemistry and Physics, 56: 266 -270 .

25. Tong, M., Dai, G. and Gao, D. (2001). $\mathrm{WO}_{3}$ thin film sensor prepared by sol-gel technique and its lowtemperature sensing properties to trimethylamine. Materials Chemistry and Physics, 69: 176 - 179.

26. Enesca, A., Duta, A. and Schoonman, J. (2007). Study of photoactivity of tungsten trioxide $\left(\mathrm{WO}_{3}\right)$ for water splitting. Thin Solid Films, 515: 6371 - 6374.

27. Gavrilyuk, A. I. (2009). Application of $\mathrm{WO}_{3}$ thin films for enhancement of photolysis in AgCl. Solar Energy Materials and Solar Cells, 93: 1885 - 1895.

28. Hong, S. J., Jun, H., Borse, P. H. and Lee, J. S. (2009). Size effects of $\mathrm{WO}_{3}$ nanocrystals for photooxidation of water in particulate suspension and photoelectrochemical film systems. International Journal of Hydrogen Energy, 34: $3234-3242$.

29. Su, L., Dai, Q. and Lu, Z. (1999). Spectroelectrochemical and photoelectrochemical studies of electrodeposited tungsten trioxide films. Spectrochimica Acta Part A, 55: 2179 - 2185.

30. Bamwenda, G. R. and Arakawa, H. (2001). The visible light induced photocatalytic activity of tungsten trioxide powder. Applied Catalysis A, 210: $181-191$.

31. Sigh, A. P., Kumari, S., Shrivastav, R., Dass, S. and Satsangi, V. R. (2008). Iron doped nanostructured $\mathrm{TiO}_{2}$ for photoelectrochemical generation of hydrogen. International Journal of Hydrogen Energy 33: 5363 - 5368.

32. Hameed, A., Gondal, M. A. and Yamani, Z. H. (2004). Effect of transition metal doping on photocatalytic activity of $\mathrm{WO}_{3}$ for water splitting under laser illumination: role of 3d-orbitals. Catalysis Communication, 5: $715-719$.

33. Saremi-Yarahmadi, S., Tahir, A. A., Vaidhyanathan, B. and Wijayantha, K. G. U. (2008). Fabrication of nanostructured $\alpha-\mathrm{Fe}_{2} \mathrm{O}_{3}$ electrodes using ferrocene for solar hydrogen generation. Material Letters, 53: 523 526.

34. Minggu, L. J., Daud, W. R. W. and Kassim, M. B. (2010). An overview of photocells and photoreactors for photoelectrochemical water splitting. International Journal of Hydrogen Energy 35: 5233 - 5244.

35. Yagi, M., Maruyama, S., Sone, K., Nagai, K. and Norimatsu, T. (2008). Preparation and photoelectrocatalytic activity of a nano-structured $\mathrm{WO}_{3}$ platelet film. Journal of Solid State Chemistry, 181: $175-182$.

36. Solarska, R., Alexander, B. D. and Augustynski, J. (2006). Electrochromic and photoelectrochemical characteristics of nanostructured $\mathrm{WO}_{3}$ films prepared by a sol-gel method. Comptes Rendus Chimie, 9: 301 306.

37. Ng, K. H., Minggu, L. J., Jumali, M. H. H. and Kassim, M. B. (2012). Fotoelektrod tungsten trioksida terdop nikel untuk tindak balas pembelahan air fotoelektrokimia. Sains Malaysiana, 41(7): 893 - 899

38. Upadhyay, S. B., Mishra, R. K. and Sahay, P. P. (2014). Structural and alcohol response characteristics of Sndoped $\mathrm{WO}_{3}$ nanosheets. Sensors and Actuators B: Chemical 193: 19 - 27.

39. Boudjemaa, A. and Trari, M. (2010). Photo-catalytic hydrogen production over $\mathrm{Fe}_{2} \mathrm{O}_{3}$ based catalysts. International Journal of Hydrogen Energy, 35: 7684 - 7689.

40. Łącz, A. and Pasierb P. (2013). Synthesis of $\mathrm{BaCe}_{1-\mathrm{x}} \mathrm{Y}_{\mathrm{x}} \mathrm{O}_{3-\delta}-\mathrm{BaWO}_{4}$ composite protonic conductors. Journal of Thermal Analysis and Calorimetry, 113: 405-412.

41. Sun, Y., Murphy, C. J., Reyes-Gil, K. R., Reyes-Garcia, E. A., Thornton, J. M., Morris, N. A. and Raftery, D. (2009). Photoelectrochemical and structural characterization of carbon-doped $\mathrm{WO}_{3}$ films prepared via spray pyrolysis. International Journal of Hydrogen Energy, 34: 8476 - 8484.

42. Redecka, M., Rekas, M., Trenczek-Zajac, A. and Zakrzewska, K. (2008). Importance of the band gap energy and flat band potential for application of modified $\mathrm{TiO}_{2}$ photoanodes in water photolysis. Journal of Power Sources, 181: $46-55$.

43. Suk, J. H., Jun, H., Borse, P. H. and Lee, J. S. (2009). Size effects of $\mathrm{WO}_{3}$ nanocrystals for photooxidation of water in particulate suspension and photoelectrochemical film systems. International Journal of Hydrogen Energy, 34: $3234-3242$. 